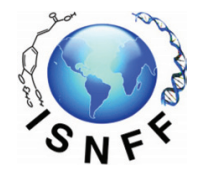

\title{
The use of oak chips during the fermentation process: effects on phenolic compounds profile and antioxidant activity in Syrah young wines
}

\author{
Natália Manzatti Machado Alencara, Cinthia Baú Betim Cazarinª Luiz Cláudio Corrêa ${ }^{\mathrm{b}}$, \\ Mário Roberto Maróstica Junior ${ }^{\mathrm{a}}$, Davi José Silva ${ }^{\mathrm{b}}$, Aline Camarão Telles Biasoto ${ }^{\mathrm{b}^{*}}$ \\ and Jorge Herman Behrens ${ }^{\mathrm{a}}$
}

\begin{abstract}
aDepartment of Food and Nutrition, University of Campinas, Campinas, São Paulo 13083-862, Brazil
${ }^{b}$ Brazilian Agricultural Research Corporation, Petrolina, Pernambuco 56302-970, Brazil

*Corresponding author: Aline Camarão Telles Biasoto, Brazilian Agricultural Research Corporation, Petrolina, Pernambuco 56302-970, Brazil. E-mail: aline.biasoto@embrapa.br

DOI: $10.31665 /$ JFB.2020.10229

Received: March 31, 2020; Revised received \& accepted: June 18, 2020

Citation: Alencar, N.M.M., Cazarin, C.B.B., Corrêa, L.C., Junior, M.R.M., Silva, D.J., Biasoto, A.C.T, and Behrens, J.H. (2020). The use of oak chips during the fermentation process: effects on phenolic compounds profile and antioxidant activity in Syrah young wines. J. Food Bioact. 10: 70-76.
\end{abstract}

\begin{abstract}
The use of oak chips is an alternative method to the traditional barrels in winemaking in order to improve the aged quality of the red wines. This study investigated the influence of adding of oak chips during the fermentation process on phenolic compounds profile and antioxidant activity. The American (Quercus alba) and/or French (Quercus petreae) oak chips were added ( $4 \mathrm{~g} \mathrm{~L}^{-1}$ doses) in the alcoholic fermentation and malolactic fermentation or malolactic fermentation alone. Results indicated that Syrah tropical wines presented higher levels $\left(\geq 265 \mathrm{mg} \mathrm{L}^{-1}\right)$ of phenolic compounds compared to wines fermented with oak chips (223-254 mg $\left.\mathrm{L}^{-1}\right)$. Twenty-five phenolics were identified among the wine samples, with gallic $\left(70.67 \mathrm{mg} \mathrm{L}^{-1}\right)$ and malvidin-3-O-glucoside $\left(68.30 \mathrm{mg} \mathrm{L}^{-1}\right)$ as the main compounds. However, the wine with French oak chip added during malolactic fermentation showed a higher antioxidant activity, when using ORAC assay. This study offers a practical application of oak chips in winemaking process as an alternative to produce high quality young red wines with low cost to the wineries in places of oak barrels.
\end{abstract}

Keywords: Vitis vinifera L.; Bioactive compounds; HPLC-DAD-FD; In vitro antioxidant assays; Tropical red wine.

\section{Introduction}

The ageing of wine in wood barrel for red wines is a traditional and commonly applied technique in winemaking that promotes several advantages. One of the most important effects is on color stability due to compounds derived from wood (e.g., gallic acid, syringic acid, vanillic acid, ferulic acid, ellagic acid, and ellagitannins), which migrate from wood to wine (Durner, 2016). Both American (Q. alba) and French (Q. petraea) oak significantly improve the content of phenolic compounds in wine, causing less color changes during the storage in the bottle (Liu et al., 2016), and may con- tribute to increased concentration of anthocyanins in young wines (Rodriguez-Solana et al., 2017). On the other hand, during the aging in wood barrels for at least six months, the concentration of important aroma compounds, such as oak lactones, increase and improve the wine's sensory characteristics, particularly aromas related to red fruits, vanilla, and coconut (Jackson, 2014).

The use of oak chip in winemaking is an alternative to the traditional barrels (Arapitsas et al., 2004; Frangipane et al., 2007), and the chip of Quercus genus is authorized by the International Oenological Codex in 2005, since they are an economically advantageous alternative for winemakers in regions where oak is unavailable. Moreover. oak chips demand less time to attain the 
similar characteristics to those of wines aged in barrels (CejudoBastante et al., 2011).

There are several studies on the application of oak chip in different steps of winemaking (e.g.,alcoholic fermentation, malolactic or after fermentation) (Gallego et al., 2015a). In general, the amount of oak chips used in the studies with red wine varies from 3 to $9 \mathrm{~g} \mathrm{~L}^{-1}$ (Alañón et al., 2011; Cejudo-Bastante et al., 2011).

The main objective of this study was to evaluate the application of American or French (or mixtures) oak chip in tropical wine during alcoholic or malolactic fermentation on the phenolic compounds and the antioxidant activity and check if the the type of oak and stage of fermentation of infusion the oak chip was able to improve the quality of young wines. This is the first study that uses oak chips during the fermentation process of Syrah wine produced in the Vale do São Francisco, Brazil, and evaluates the effects on phenolic compounds profile and antioxidant activity.

\section{Materials and methods}

\subsection{Chemicals and oenological materials}

The oenological materials to the winemaking potassium metabisulfite, Saccharomyces cerevisiae bayanus Maurivin $\mathrm{PDM}^{\circledR}$ (Amazon Group, Rio de Janeiro, RJ, Brazil) and ammonium phosphate Gesferm Plus ${ }^{\circledR}$ were obtained from Amazon Group (Rio de Janeiro, RJ, Brazil), pectinolytic enzyme Pectozim Rouge ${ }^{\circledR}$ was purchased from Ever (Garibaldi, RS, Brazil) and the mixture of gum Arabic and metatartaric acid Stabigum ${ }^{\circledR}$ from AEB Group (São José dos Pinhais, PR, Brazil). Folin-Ciocalteu's phenol reagent, TPTZ (2,4,6-tris(2-pyridyl)-S-triazine), AAPH (2,2'-azobis(2-methylpropionamidine dihydrochloride) and Trolox (6-hydroxy-2,5,7,8tetramethylchroman-2-carboxylic acid-Sigma-Aldrich, St. Louis, MO, USA) were the reagents used to analysis of total phenolic compounds and antioxidant activity.

Twenty-five standards of phenolic compounds were used to prepare the calibration curves for the HPLC analysis: ferulic acid and quercetin (ChemService, West Chester, PA, USA); caffeic, $p$ coumaric, chlorogenic and gallic acids (Sigma-Aldrich, St. Louis, MO, U.S.A.); kaempferol-3-O-glucoside, myricetin, isorhamnetin-3-O-glucoside, quercetin 3- $\beta$-D-glucoside, rutin, $(+)$-catechin, $(-)$-epicatechin, (-)-epicatechin gallate, (-)-epigallocatechin gallate, procyanidin $\mathrm{A} 2$, procyanidin $\mathrm{B} 1$, procyanidin $\mathrm{B} 2$, pelargonidin-3-O-glucoside, cyanidin-3-O-glucoside, malvidin-3-Oglucoside, delphinidin-3-O-glucoside, peonidin-3-O-glucoside, petunidin 3-O-glucoside and trans-resveratrol (Extrasynthese, Genay, France). As mobile phases, HPLC grade acetonitrile was purchased from JT Baker (Phillipsburg, N.J., U.S.A), phosphoric acid from Fluka (Buchs, Switzerland) and HPLC grade methanol from Vetec Quimica (Rio de Janeiro, Brazil) for cleaner the system.

\subsection{Winemaking}

Syrah grapes (Vitis vinifera L.) cultivated in the experimental field of the Embrapa Semi-Arid, Petrolina, Brazil, situated at $09^{\circ} 09^{\prime} \mathrm{S}$ and $40^{\circ} 22^{\prime} \mathrm{W}$, with medium altitude with 365.5 meters, were harvested in July 2015.

After destemming in a commercial destemmer (Ricefer, Garibaldi, RS, Brazil), the grapes were transferred to a $25 \mathrm{~L}$ stainless steel vat with the addition of potassium metabisulfite $\left(0.10 \mathrm{~g} \mathrm{~L}^{-1}\right)$. The alcoholic fermentation was started under controlled tempera- ture $\left(24 \pm 2{ }^{\circ} \mathrm{C}\right)$ with the addition of pectinolytic enzyme $(0.01 \mathrm{~g}$ $\left.\mathrm{L}^{-1}\right)$, commercial yeast Saccharomyces cerevisiae bayanus $(0.20$ $\left.\mathrm{g} \mathrm{L}^{-1}\right)$, and ammonium phosphate $\left(0.20 \mathrm{~g} \mathrm{~L}^{-1}\right)$ to the musts. The maceration period (skins and seeds) was conducted in 30 days along with alcoholic and malolactic fermentation (Alencar et al., 2019). The alcoholic fermentation lasted 20 days, and the end was determined by measuring the density in hydrostatic electronic balance (Gibertini, Milan, Italy) until it remained constant, lower than 0.997 and the reducing sugars content was below $2 \mathrm{~g} \mathrm{~L}^{-1}$ (Ribéreau-Gayon et al., 2006). The skins and seeds were separated from the wine through pressing at 50 bar using a horizontal press (Control Tech Automação, Caxias do Sul, Brazil). The spontaneous malolactic fermentation was performed under controlled temperature $\left(18 \pm 1{ }^{\circ} \mathrm{C}\right)$ and the end (30 days) was verified by paper chromatography to check the presence of malic acid. At the end of this stage, the wine was transferred to retain yeasts and suspended particles.

American and/or French oak chips $\left(4 \mathrm{~g} \mathrm{~L}^{-1}\right)$ were added either at the start of the alcoholic or malolactic fermentation (GarcíaCarpintero et al., 2014; Gordillo, Cejudo-Bastante et al., 2013) placed in nylon bags positioned at the center of the tank.

French oak chips (AEB-group, France), in pieces of $2.5 \times 5.0$ $\times 0.5 \mathrm{~cm}, 100 \%$ of Quercus petreae, with higher roasting, and American oak chips (Everintec, Italy), in pieces of $2.5 \times 2.0 \times$ $1.0 \mathrm{~cm} ; 100 \%$ Quercus alba, medium roasting. The aging treatments were: WC (control wine without oak chips), WAAMF (wine added American oak chip in alcoholic and malolactic fermentation), WAMF (wine added American oak chip in malolactic fermentation), WFAMF (wine added French oak chip in alcoholic and malolactic fermentation), WFMF (wine added with French oak chip during malolactic fermentation) and WAFAMF (wine added with American and French oak chips in both fermentation). For the wines that received the oak chip in the alcoholic and malolactic fermentations, chips were substituted for new ones prior to the malolactic fermentation.

Stabilization was performed in a cold chamber for 10 days at 0 ${ }^{\circ} \mathrm{C}$ and using Stabigum $\left(0.40 \mathrm{~g} \mathrm{~L}^{-1}\right)$. Afterward, the wine was bottled $(750 \mathrm{~mL})$, the concentration of free $\mathrm{SO}_{2}$ was corrected to 50 $\mathrm{mg} \mathrm{L}^{-1}$ (Ribéreau-Gayon et al., 2006), and stored in a cellar at 18 ${ }^{\circ} \mathrm{C}$ in the horizontal position for 30 days until analysis.

\subsection{Oenological quality parameters}

The analysis of the oenological quality parameters, namely $\mathrm{pH}$, total titrable acidity, volatile acidity, alcohol content, reducing sugars, free and total sulfur dioxide, were carried out according to the standard method of the Association of Official Analytical Chemists (2007). The total polyphenol index (TPI) was performed with wine dilutions of $1: 100$, followed by reading absorbance at $280 \mathrm{~nm}$ using a spectrophotometer Genesys ${ }^{\mathrm{TM}} 10 \mathrm{~S}$ (Thermo Fisher Scientific, Waltham, MA) in Q-4 quartz cuvettes (Ribéreau-Gayon et al., 2006) (Table S1).

\subsection{Color intensity}

Color intensity was measured in terms of absorbance at different wavelengths $(420,520$, and $620 \mathrm{~nm})$, using a spectrophotometer Genesys $^{\text {TM }}$ 10S (Thermo Fisher Scientific, Waltham, MA, USA). The color intensity value was obtained by summing the absorbance measurements of the wine in the violet, green, and red regions of the visible spectrum, according to Ribéreau-Gayon et al. (2006). 


\subsection{Total phenolic compounds, monomeric anthocyanins and condensed tannins}

The phenolic compounds were quantified using the Folin-Ciocalteu method (Swain and Hills, 1959). Aliquots of $800 \mu \mathrm{L}$ of deionized water and $50 \mu \mathrm{L}$ of Folin-Ciocalteu's phenol reagent were mixed using a vortex with $50 \mu \mathrm{L}$ of the wine. The mixture was allowed to stand for $3 \mathrm{~min}$ to react and sequentially $100-\mu \mathrm{L}$ of $0.5 \mathrm{M}$ $\mathrm{Na}_{2} \mathrm{CO}_{3}$ solution was added. The solution was incubated in a dark place $\left(24^{\circ} \mathrm{C}\right)$ for $2 \mathrm{~h}$ and then the absorbance was read at $725 \mathrm{~nm}$ using a UV-Vis multi-detection microplate reader (Synergy HT, Biotek, Winooski, VT, USA). The results were expressed as gallic acid equivalents (GAE mg L $\mathrm{m}^{-1}$ ) using a standard curve prepared with gallic acid.

Total monomeric anthocyanins were determined by the $\mathrm{pH}$ differential method (Lee et al., 2005). Wine aliquots were diluted in $0.025 \mathrm{M} \mathrm{HCl}-\mathrm{KCl}$ buffer ( $\mathrm{pH} \mathrm{1.0)}$ ), and the absorbance was measured at 520 and $700 \mathrm{~nm}$ in a microplate reader (Synergy HT, Biotek, Winooski, VT, USA). Another dilution was made in $0.4 \mathrm{M}$ $\mathrm{C}_{2} \mathrm{H}_{3} \mathrm{NaO}_{2}$ buffer ( $\mathrm{pH} 4.5$ ) and the absorbance was read at the same wavelengths. The calculation was performed using Equation 1. The quantification of total monomeric anthocyanins was done using malvidin-3-O-glucoside (MW 493.2) as a reference in Equation 2:

$$
\begin{gathered}
\mathrm{A}=\left[(\mathrm{A} 520-\mathrm{A} 700 \mathrm{~nm}) \mathrm{pH}={ }_{1.0}\right] \\
-\left[(\mathrm{A} 520-\mathrm{A} 700 \mathrm{~nm}) \mathrm{pH}={ }_{4.5}\right] \\
\mathrm{C}\left(\mathrm{mg} \text { malvidin } 3-O \text {-glucoside } \mathrm{L}^{-1}\right)
\end{gathered}
$$

Where: $\mathrm{MW}=$ molecular weight; $\mathrm{DF}=$ dilution factor; $£=$ molar absorptivity $\left(28,000 \mathrm{~mol} \mathrm{~L}^{-1}\right)$ and $1=$ path length $(\mathrm{cm})$.

The content of total condensed tannins was determined by Vannilin- $\mathrm{HCl}$ method following the methodology described by Harbertson and Spayd (2006). The results were expressed as mg of vanillin equivalents per $\mathrm{mL}\left(\mathrm{VE} \mathrm{mg} \mathrm{mL}^{-1}\right)$.

\subsection{Identification and quantification of phenolic compounds}

Chromatographic identification and quantification of phenolic compounds was performed by HPLC-DAD-FD (Waters 2695 Aliance system, Milford, MA, USA) using the wavelengths 280, 320,360 , and $520 \mathrm{~nm}$ for the diode array detector (DAD) and $280 \mathrm{~nm}$ excitation and $320 \mathrm{~nm}$ emission for the fluorescence detector (FD), according to Natividade et al. (2013) following the validation parameters (Table S2). Data acquisition and processing were carried out in a Waters Empower TM 2 software (Milford, MA, USA). Briefly, pre-Gemini-NX C18 column $(4.0 \times 3.0 \mathrm{~mm}$, Phenomenex ${ }^{\circledR}$, Torrance, CA, USA) and Gemini-NX C18 column $\left(150 \times 4.60 \mathrm{~mm} \times 3.0 \mu \mathrm{m}\right.$, Phenomenex ${ }^{\circledR}$, Torrance, CA, USA $)$ were used to separate the compounds. Prior to injection, samples $(500 \mu \mathrm{L})$ were diluted to $1 \mathrm{~mL}$ with $0.85 \%$ phosphoric acid solution. The mobile phases used were $0.85 \%$ phosphoric acid solution (A) and acetonitrile (B). The running conditions were: $0.5 \mathrm{~mL}$ $\min ^{-1}$ flow rate, $40{ }^{\circ} \mathrm{C}$ oven temperature, $10 \mu \mathrm{L}$ injection volume; using a gradient elution as follows: $0 \mathrm{~min} 100 \% \mathrm{~A} ; 10 \mathrm{~min}, 93 \% \mathrm{~A}$; $20 \mathrm{~min}, 90 \% \mathrm{~A} ; 30 \mathrm{~min}, 88 \% \mathrm{~A} ; 40 \mathrm{~min}, 77 \% \mathrm{~A} ; 45 \mathrm{~min}, 65.0 \% \mathrm{~A}$, and $100 \% \mathrm{~B}$ at $55 \mathrm{~min}$ (totaling $60 \mathrm{~min}$ of running). The samples were filtered in a $0.45 \mu \mathrm{m}$ nylon membrane (Phenomenex).

\subsection{Antioxidant activity analysis}

The antioxidant activity of the wines was evaluated by the reaction with FRAP reagent (Rufino et al., 2010; Benzie and Strain, 1996). The samples were incubated for $30 \mathrm{~min}$ at $37^{\circ} \mathrm{C}$, and the absorbance was measured at $595 \mathrm{~nm}$ (Synergy HT, Biotek, Winooski, VT, USA). A Trolox standard curve was used, and the results were expressed as $\mu \mathrm{mol}$ Trolox equivalents (TE) $\mathrm{L}^{-1}$ (Benzie and Strain, 1996).

ORAC (hydrophilic oxygen radical absorbance capacity) (Ou et al., 2013) was also used to evaluate the antioxidant activity of the wines. The wines were diluted in phosphate buffer $\left(75 \mathrm{mmol} \mathrm{L}^{-1}\right.$, $\mathrm{pH}$ 7.4). Sequentially the peroxyl radical was generated through the spontaneous decomposition of AAPH at $37^{\circ} \mathrm{C}$ and fluorescein was used as a fluorescent probe. The decay of the fluorescence was read in a microplate reader (Synergy HT, Biotek, Winooski, VT, USA) using emission filter at $520 \mathrm{~nm}$ and excitation at $485 \mathrm{~nm} \mathrm{~A}$ Trolox standard curve was used, and the results were expressed as $\mu \mathrm{mol}$ Trolox equivalents (TE) $\mathrm{L}^{-1}$.

\subsection{Statistical analysis}

The results were expressed as means \pm standard deviation. For each parameter, wine samples collected from three bottles were analyzed. Analysis of variance and Tukey's means comparison test were performed to check for significant differences $(p<0.05)$. The statistical analyses were carried out using the software XLStat (Addinsoft, 2019).

\section{Results and discussion}

The concentration of total monomeric anthocyanins ranged from 298 to 351 malvidin-3-O-glucoside equivalents $\mathrm{mg} \mathrm{L}^{-1}$ in the wines and no significant difference $(p<0.05)$ was observed between the six treatments (Fig. 1a). The fermentation with the oak chip did not significantly change the amount of monomeric anthocyanins as well as total phenolic compounds content (total reduced capacity), suggesting that the addition of different oak chips and the time that the oak chips were in contact with the wine did not affect the Syrah wine characteristics (Fig. 1b). However, a decrease in condensed tannins was observed when French oak was added during the alcoholic and malolactic fermentations (WFAMF) (Fig. 1c).

Twenty-five phenolic compounds were identified in the Syrah wines (Table 1). Among them, ferulic acid and (+)-catechin did not show differences $(p<0.05)$ among the treatments. Two phenolic acids appeared among the major phenolic compounds in the wines, especially in the control sample: gallic acid $\left(70.67 \mathrm{mg} \mathrm{L}^{-1}\right)$ and chlorogenic acid $\left(5.27 \mathrm{mg} \mathrm{L}^{-1}\right)$. It seems that the amount of oak chips $\left(4 \mathrm{~g} \mathrm{~L}^{-1}\right)$ used in the present study was not enough to promote an increase in these acids in the wines, in contrast to the study by Liu et al. (2016) that reported an increase in phenolic acids (chlorogenic acid, gallic acid, caffeic acid) content after the addition of $5 \mathrm{~g} \mathrm{~L}^{-1}$ of French oak chip in the alcoholic and malolactic fermentation, a slightly higher amount of chips as compared to the present study. Regardless of the oak chip, the content of caffeic acid was greater in the samples where both alcoholic and malolactic fermentations took place when compared with the ones in which only the malolactic fermentation was performed.

The use of the oak chip during the fermentation process produced changes in the flavonols aglycones and procyanidins concentrations, as well as in tannins that might have underwent transformations such as combination with monomeric flavanols as suggested by Ribéreau-Gayon et al. (2006). It is observed that 


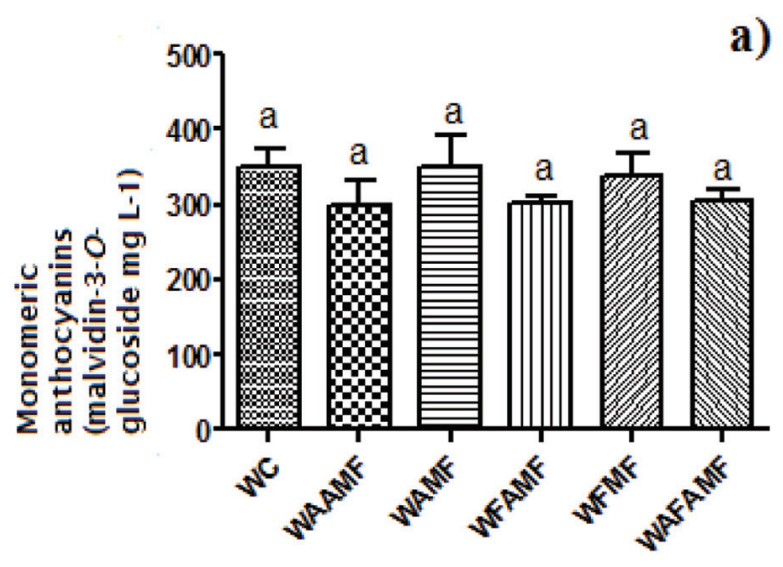

a)

b)
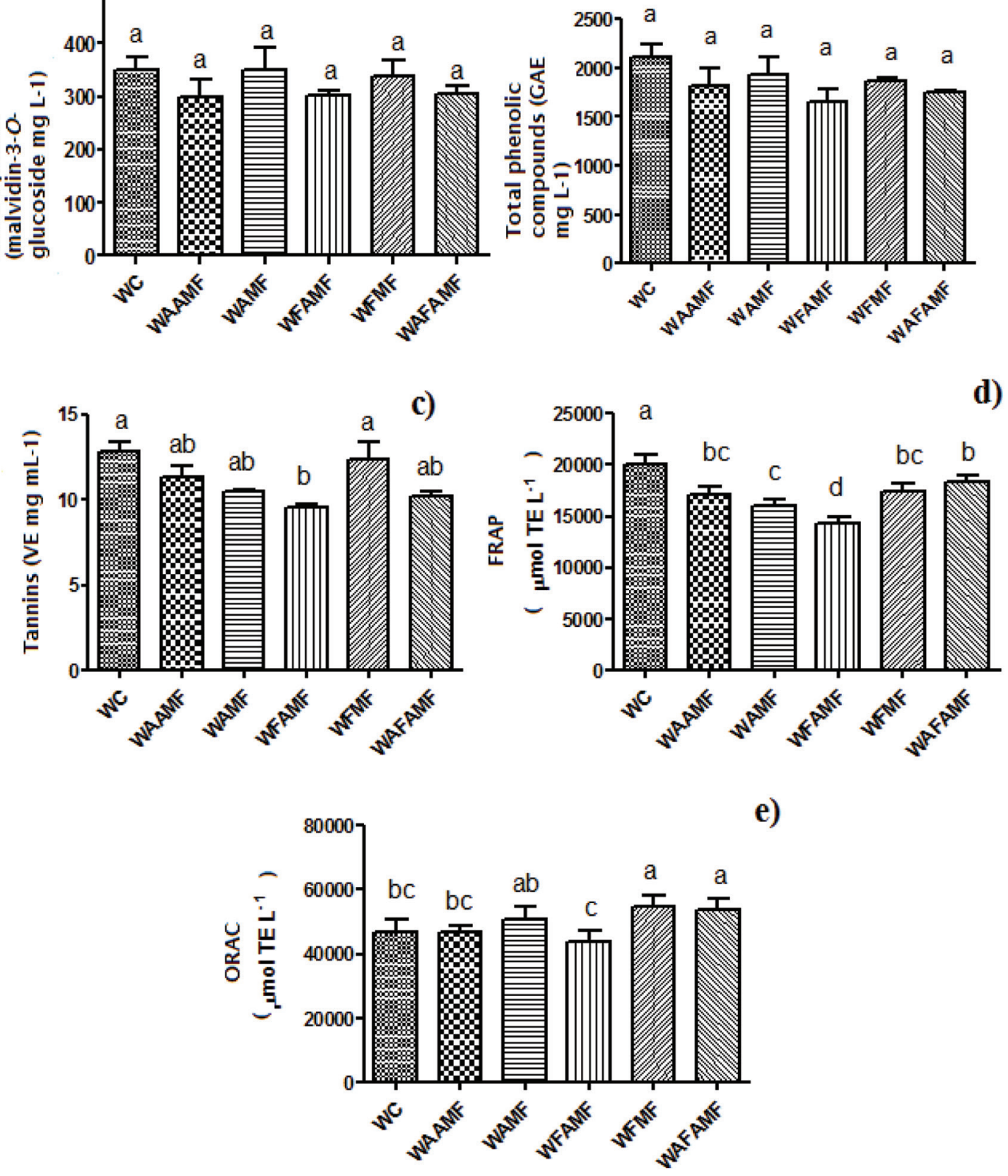

e)

Figure 1. Monomeric anthocyanins compounds in Syrah tropical wines aged with American and French oak chips (a), total phenolic (b), condensed tannins (c), antioxidant activity by the FRAP (d) and ORAC (e). Bars sharing different superscript are significantly different by the Tukey test $(p<0.05)$. ${ }^{*} A b-$ breviations: WC (control wine without oak chips), WAAMF (wine added American oak chip in alcoholic and malolactic fermentation), WAMF (wine added American oak chip in malolactic fermentation), WFAMF (wine added French oak chip in alcoholic and malolactic fermentation), WFMF (wine added with French oak chip during malolactic fermentation) and WAFAMF (wine added with American and French oak chips in both fermentation).

wine control (WC) showed higher concentrations of (-)-epigallocatechin gallate; procyanidin A2 and B2. The content of most individual tannins in French oak chip samples decreased when alcoholic and malolactic fermentations were used, as opposed to samples where only malolactic fermentation was carried out (Table 1). This result agrees with the total condensed tannins estimation (Fig. 1a). High amounts of $(+)$-catechin were found in all the wines independent of the treatment adopted during the fermentation process; however, the use of both chips decreased the amounts of the isomer (-)-epicatechin. The decrease in flavan-3-ol monomers in wine during oak aging has been described in the literature (Gallego et al., 2015b) and may be related to the polymerization reactions (Es-Safi et al., 1999). Procyanidin B2 was the predominant procyanidin in all wines, and the control wine showed the high- 
Table 1. Phenolic compounds ( $\mathrm{mg} \mathrm{L}^{-1}$ ) of Syrah tropical wines fermented with American and French oak chips

\begin{tabular}{|c|c|c|c|c|c|c|}
\hline \multirow{2}{*}{ Phenolic Compounds } & \multicolumn{6}{|c|}{ Wines } \\
\hline & WC & WAAMF & WAMF & WFAMF & WFMF & WAFAMF \\
\hline \multicolumn{7}{|l|}{ Phenolic acids } \\
\hline$p$-Coumaric acid & $0.20^{\mathrm{a}} \pm 0.00$ & $0.10^{b} \pm 0.00$ & $0.20^{\mathrm{a}} \pm 0.00$ & $0.10^{b} \pm 0.00$ & $0.10^{b} \pm 0.00$ & $0.20^{\mathrm{a}} \pm 0.00$ \\
\hline Ferulic acid & $0.10^{\mathrm{a}} \pm 0.00$ & $0.10^{\mathrm{a}} \pm 0.00$ & $0.10^{\mathrm{a}} \pm 0.00$ & $0.10^{\mathrm{a}} \pm 0.00$ & $0.10^{\mathrm{a}} \pm 0.00$ & $0.10^{\mathrm{a}} \pm 0.00$ \\
\hline Caffeic acid & $3.47^{e} \pm 0.06$ & $6.93^{\mathrm{ab}} \pm 0.46$ & $5.87^{c d} \pm 0.15$ & $7.83^{\mathrm{a}} \pm 0.50$ & $5.47^{d} \pm 0.15$ & $6.43^{b c} \pm 0.38$ \\
\hline Gallic acid & $70.67^{a} \pm 1.50$ & $63.63^{c} \pm 0.72$ & $68.80^{\mathrm{ab}} \pm 0.90$ & $65.20^{b c} \pm 0.90$ & $68.83^{\mathrm{ab}} \pm 1.87$ & $68.37^{\mathrm{ab}} \pm 1.64$ \\
\hline Chlorogenic acid & $5.27^{a} \pm 0.06$ & $2.03^{c} \pm 0.06$ & $1.63^{d} \pm 0.06$ & $1.53^{d} \pm 0.06$ & $2.27^{b} \pm 0.06$ & $2.13^{b c} \pm 0.06$ \\
\hline Total & $79.71 \pm 1.62$ & $72.79 \pm 1.24$ & $76.6 \pm 1.1$ & $74.76 \pm 1.46$ & $76.77 \pm 2.08$ & $77.23 \pm 2.08$ \\
\hline \multicolumn{7}{|l|}{ Flavanols and Procyanidins } \\
\hline (-)-Epicatechin & $7.10^{\mathrm{a}} \pm 0.40$ & $4.87^{d} \pm 0.42$ & $5.97^{b c} \pm 0.06$ & $5.20^{c d} \pm 0.30$ & $6.90^{\mathrm{ab}} \pm 0.53$ & $5.33^{\mathrm{cd}} \pm 0.40$ \\
\hline (+)-Catechin & $12.50^{\mathrm{a}} \pm 1.10$ & $11.10^{\mathrm{a}} \pm 1.01$ & $12.05^{a} \pm 0.55$ & $12.65^{a} \pm 1.05$ & $12.30^{\mathrm{a}} \pm 0.90$ & $12.50^{\mathrm{a}} \pm 1.23$ \\
\hline (-)-epigallocatechin gallate & $1.50^{\mathrm{a}} \pm 0.00$ & $1.03^{c} \pm 0.06$ & $1.17^{b c} \pm 0.06$ & $1.20^{\mathrm{b}} \pm 0.10$ & $1.20^{\mathrm{b}} \pm 0.10$ & $1.17^{\mathrm{bc}} \pm 0.06$ \\
\hline (-)-epicatechin gallate & $6.03^{c} \pm 0.51$ & $5.53^{c} \pm 0.47$ & $5.90^{c} \pm 0.53$ & $7.97^{\mathrm{a}} \pm 0.15$ & $7.30^{\mathrm{ab}} \pm 0.53$ & $6.67^{b c} \pm 0.38$ \\
\hline Procyanidin A2 & $0.60^{\mathrm{a}} \pm 0.00$ & $0.40^{\mathrm{b}} \pm 0.10$ & $0.40^{\mathrm{b}} \pm 0.10$ & $0.25^{b c} \pm 0.05$ & $0.28^{b c} \pm 0.08$ & $0.20^{c} \pm 0.00$ \\
\hline Procyanidin B1 & $8.63^{\mathrm{a}} \pm 0.61$ & $6.17^{c} \pm 0.49$ & $7.80^{\mathrm{ab}} \pm 0.35$ & $6.40^{c} \pm 0.44$ & $8.30^{\mathrm{a}} \pm 0.44$ & $6.77^{b c} \pm 0.25$ \\
\hline Procyanidin B2 & $19.07^{\mathrm{a}} \pm 0.55$ & $14.03^{d} \pm 1.40$ & $16.07^{b c} \pm 0.32$ & $14.90^{\mathrm{cd}} \pm 0.60$ & $17.10^{b} \pm 0.32$ & $14.40^{c d} \pm 0.26$ \\
\hline Total & $55.43 \pm 3.17$ & $43.13 \pm 3.95$ & $49.36 \pm 1.97$ & $48.57 \pm 2.69$ & $53.38 \pm 2.9$ & $47.04 \pm 2.58$ \\
\hline \multicolumn{7}{|l|}{ Flavonols aglycones } \\
\hline Isorhamnetin-3-O-glucoside & $13.97^{\mathrm{a}} \pm 0.23$ & $11.67^{d} \pm 0.51$ & $12.67^{b c} \pm 0.38$ & $12.10^{\text {cd }} \pm 0.26$ & $13.43^{\mathrm{ab}} \pm 0.31$ & $12.63^{b c} \pm 0.31$ \\
\hline Quercetin 3- $\beta$-D-glucoside & $1.05^{\mathrm{a}} \pm 0.15$ & $0.60^{b c} \pm 0.10$ & $0.70^{b} \pm 0.10$ & $0.40^{c} \pm 0.00$ & $0.55^{b c} \pm 0.05$ & $0.40^{c} \pm 0.00$ \\
\hline Quercetin & $20.73^{\mathrm{a}} \pm 0.35$ & $17.43^{c} \pm 0.74$ & $18.77^{b c} \pm 0.57$ & $17.90^{c} \pm 0.53$ & $19.90^{\mathrm{ab}} \pm 0.44$ & $18.83^{b c} \pm 0.50$ \\
\hline Kaempferol-3-O-glucoside & $2.07^{\mathrm{a}} \pm 0.06$ & $1.67^{d} \pm 0.06$ & $1.83^{\mathrm{bc}} \pm 0.06$ & $1.77^{c d} \pm 0.06$ & $1.97^{\mathrm{ab}} \pm 0.06$ & $1.83^{\mathrm{bc}} \pm 0.06$ \\
\hline Rutin & $1.60^{\mathrm{a}} \pm 0.10$ & $1.27^{c} \pm 0.06$ & $1.40^{b c} \pm 0.00$ & $1.33^{c} \pm 0.06$ & $1.50^{\mathrm{ab}} \pm 0.00$ & $1.40^{\mathrm{bc}} \pm 0.00$ \\
\hline Myricetin & $4.57^{\mathrm{a}} \pm 0.12$ & $3.73^{c} \pm 0.15$ & $4.00^{b c} \pm 0.10$ & $3.87^{c} \pm 0.12$ & $4.23^{\mathrm{ab}} \pm 0.15$ & $4.00^{b c} \pm 0.10$ \\
\hline Total & $43.99 \pm 1.01$ & $36.37 \pm 1.62$ & $39.37 \pm 1.21$ & $37.37 \pm 1.03$ & $41.58 \pm 1.01$ & $39.09 \pm 0,97$ \\
\hline \multicolumn{7}{|l|}{ Anthocyanins } \\
\hline Cyanidin 3-O-glucoside & $0.40^{\mathrm{a}} \pm 0.00$ & $0.20^{\mathrm{a}} \pm 0.00$ & $0.20^{\mathrm{a}} \pm 0.00$ & $0.20^{\mathrm{a}} \pm 0.00$ & $0.30^{\mathrm{a}} \pm 0.00$ & $0.20^{\mathrm{a}} \pm 0.00$ \\
\hline Peonidin 3-O-glucoside & $4.37^{a} \pm 0.06$ & $3.23^{c} \pm 0.06$ & $3.03^{d} \pm 0.06$ & $2.87^{d} \pm 0.06$ & $3.83^{b} \pm 0.06$ & $3.00^{d} \pm 0.10$ \\
\hline Petunidin 3-O-glucoside & $0.80^{\mathrm{a}} \pm 0.00$ & $0.70^{\mathrm{ab}} \pm 0.00$ & $0.63^{c} \pm 0.06$ & $0.63^{c} \pm 0.06$ & $0.77^{\mathrm{ab}} \pm 0.06$ & $0.67^{b c} \pm 0.06$ \\
\hline Delphinidin 3-O-glucoside & $3.17^{\mathrm{a}} \pm 0.06$ & $2.33^{\mathrm{c}} \pm 0.06$ & $2.10^{d} \pm 0.00$ & $2.17^{d} \pm 0.06$ & $2.63^{b} \pm 0.06$ & $2.20^{d} \pm 0.00$ \\
\hline Malvidin 3-O-glucoside & $68.30^{\mathrm{a}} \pm 1.44$ & $56.63^{b} \pm 0.42$ & $54.50^{b} \pm 0.78$ & $55.10^{b} \pm 0.82$ & $66.80^{\mathrm{a}} \pm 1.41$ & $51.20^{c} \pm 0.46$ \\
\hline Pelargonidin 3-O-glucoside & $8.67^{a} \pm 0.15$ & $6.83^{c} \pm 0.06$ & $6.23^{d} \pm 0.06$ & $6.43^{d} \pm 0.12$ & $7.80^{b} \pm 0.20$ & $6.17^{d} \pm 0.12$ \\
\hline Total & $85.71 \pm 1.71$ & $69.92 \pm 0.66$ & $66.69 \pm 0.96$ & $67.4 \pm 1.12$ & $82.13 \pm 1.79$ & $63.44 \pm 0.74$ \\
\hline \multicolumn{7}{|l|}{ Stilbenes } \\
\hline Trans-resveratrol & $0.60^{\mathrm{a}} \pm 0.00$ & $0.50^{\mathrm{a}} \pm 0.00$ & $0.50^{\mathrm{a}} \pm 0.00$ & $0.50^{\mathrm{a}} \pm 0.00$ & $0.50^{\mathrm{a}} \pm 0.00$ & $0.50^{\mathrm{a}} \pm 0.00$ \\
\hline
\end{tabular}

Values followed by different letters in the same line are significantly different according to Tukey's test $(p<0.05)$. *Abbreviations: WC (control wine without oak chips), WAAMF (wine added American oak chip in alcoholic and malolactic fermentation), WAMF (wine added American oak chip in malolactic fermentation), WFAMF (wine added French oak chip in alcoholic and malolactic fermentation), WFMF (wine added with French oak chip during malolactic fermentation) and WAFAMF (wine added with American and French oak chips in both fermentation).

est concentration of procyanidins as compared to the wines added with oak chips. The sensation of astringency is mainly influenced by the source of procyanidins (Chira et al., 2015) and according to Alencar et al. (2018), the fermentation with French chip decreased the perception of astringency compared to the wine without the chip, due to a reduction in procyanidins content.

Six anthocyanins were identified and quantified in the wines, malvidin 3-O-glucoside being the most relevant (Table 1). The ad- 
Table 2. Color intensity of Syrah tropical wines fermented with American and French oak chips

\begin{tabular}{ll}
\hline Wines & Color Intensity $(420+520+620 \mathbf{n m})$ \\
\hline WC & $13.75^{\mathrm{a}} \pm 0.64$ \\
WAAMF & $9.93^{\mathrm{c}} \pm 0.34$ \\
WAMF & $13.64^{\mathrm{a}} \pm 0.11$ \\
WFAMF & $11.08^{\mathrm{b}} \pm 0.15$ \\
WFMF & $10.71^{\mathrm{bc}} \pm 0.24$ \\
WAFAMF & $11.16^{\mathrm{b}} \pm 0.14$ \\
\hline
\end{tabular}

Values followed by different letters are significantly different $(p<0.05)$ according to Tukey's test. *Abbreviations: WC (control wine without oak chips), WAAMF (wine added American oak chip in alcoholic and malolactic fermentation), WAMF (wine added American oak chip in malolactic fermentation), WFAMF (wine added French oak chip in alcoholic and malolactic fermentation), WFMF (wine added with French oak chip during malolactic fermentation) and WAFAMF (wine added with American and French oak chips in both fermentation).

dition of oak chip during winemaking decreases the amounts of anthocyanins in the wine; however, the use of the French chips during the malolactic fermentation preserved the content of malvidin 3-O-glucoside $\left(66.80 \mathrm{mg} \mathrm{L}^{-1}\right)$ in the wine as compared to the control. Malvidin 3-O-glycoside is the most abundant anthocyanin in red wine, and it is demonstrating in the literature this anthocyanin can react with the oak phenolic during the aging process forming new products that change the wine color or flavor (Jordão et al., 2017).

The results show that the addition of oak chip in the fermentation process affected the color intensity of the wines (Table 2) $(p<$ 0.05 ). The wines WC and WAMF presented higher color intensity as compared to the other samples. Table 1 shows that in control (WC) wine the sum was significantly higher than in the wines fermented with oak chips. The color of the wines can vary due to the anthocyanins that are unstable during aging in wood, as they may react with other phenolic compounds present in the wine, especially the tannins (Ribéreau-Gayon et al., 2006).

Reduction in the antioxidant potential by FRAP assay (Fig. 1d) was observed in the wines fermented with oak compared to the control. This result is in agreement with Alañón et al. (2011) since the authors showed decreased antioxidant activity when American and French oak wood were used in the winemaking. Figure 1e still shows that the addition of the French and American oak chips during the alcoholic and malolactic fermentation (WAFAMF), improved the ability of the antioxidants present in the wine to scavenge the peroxyl radical derived from the thermal decomposition of 2,2'-azobis(2-methylpropionamidine) dihydrochloride (AAPH). The antioxidant activity of the Syrah wines evaluated, measured by the ORAC assay showed to be higher than wines from other Brazilian regions $\left(29,801 \mu \mathrm{mol} \mathrm{TE} \mathrm{L}^{-1}\right)$, Argentine $(28,966 \mu \mathrm{mol}$ $\left.\mathrm{TE} \mathrm{L}^{-1}\right)$ and Chile $\left(31,470 \mu \mathrm{mol} \mathrm{TE}^{\mathrm{L}-1}\right.$ ) (Granato et al., 2012).

\section{Conclusions}

The oak chips $\left(4 \mathrm{~g} \mathrm{~L}^{-1}\right)$ did not increase the amount of total phenolic compounds, monomeric anthocyanins, condensed tannins, and the antioxidant activity by FRAP assay. However, the addition of the French oak chip (WFMF) in malolactic fermentation and the mixture of French and American oak chips during the alcoholic and malolactic fermentation (WAFAMF) improved the antioxidant activity measured by the ORAC assay. It was also demonstrated that the fermentation with oak chip decreased the concentration of procyanidin $\mathrm{A} 2$ and $\mathrm{B} 2$ in the wine, which may be favorable to decrease astringency. Further studies should be conducted on the effect of oak chips both during fermentation and ageing processes to gain a better understanding about the stability of phenolic compounds in tropical Syrah wines and their relationship with color and antioxidant activity

\section{Acknowledgments}

This work was supported by Coordenação de Aperfeiçoamento de Pessoal de Nível Superior (CAPES) Finance Code 001; Embrapa (SEG 03.13.06.017.00.00); FACEPE (Project: APQ-0921-507/14) and CNPq (403328/2016-0; 301108/2016-1) and FAPESP (2015/50333-1; 2018/11069-5).

\section{Supplementary Material}

Suppl 1. Quality oenological parameters of Syrah tropical wines.

Suppl 2. Validation parameters of chromatographic identification and quantification of phenolic compounds performed by HPLCDAD-FD.

\section{References}

Addinsoft. (2019). Addinsoft. XLSTAT statistical and data analysis solution. Long Island, NY, USA. https://www.xIstat.com.

Alañón, M.E., Castro-Vázquez, L., Díaz-Maroto, M.C., Gordon, M.H., and Pérez-Coello, M.S. (2011). A study of the antioxidant capacity of oak wood used in wine ageing and the correlation with polyphenol composition. Food Chem. 128: 997-1002. doi:10.1016/j.foodchem.2011.04.005

Alencar, N.M.M., Ribeiro, T.G., Barone, B., Barros, A.P.A., Marques, A.T.B., and Behrens, J.H. (2019). Sensory pro fi le and check-all-that-apply ( cata ) as tools for evaluating and characterizing syrah wines aged with oak chips. Food Res. Int. 124: 156-164. doi:10.1016/j. foodres.2018.07.052.

Arapitsas, P., Antonopoulos, A., Stefanou, E., and Dourtoglou, V.G. (2004). Artificial aging of wines using oak chips. Food Chem. 86: 563-570. doi:10.1016/j.foodchem.2003.10.003.

Association of Official Analytical Chemists. (2007). Association of Official Analytical Chemists. Official methods of analysis.

Benzie, I., and Strain, J. (1996). The ferric reducing ability of plasma (FRAP) as a measure of "antioxidant power": the FRAP assay. Anal. Biochem. 239(1): 70-6. doi:10.1006/abio.1996.0292.

Cejudo-Bastante, M.J., Hermosín-gutiérrez, I., and Pérez-coello, M.S. (2011). Micro-oxygenation and oak chip treatments of red wines: Effects on colour-related phenolics, volatile composition and sensory characteristics. Part II: Merlot wines. Food Chem. 124: 738-748. doi:10.1016/j.foodchem.2010.07.064.

Chira, K., Zeng, L., Floch, A.L.E., Péchamata, L., Jourdes, M., and Teissedre, P.-L. (2015). Compositional and sensory characterization of grape proanthocyanidins and oak wood ellagitannin. Tetrahedron 71: 2999-3006. doi:10.1016/j.tet.2015.02.018

Durner, D. (2016). Improvement and Stabilization of Red Wine Color. Handbook on Natural Pigments in Food and Beverages: Industrial Applications for Improving Food Color. Elsevier Ltd, pp. 240-264. doi:10.1016/B978-0-08-100371-8.00012-9.

Es-Safi, N.-E., Fulcrand, H., Cheynier, V., and Moutounet, M. (1999). Competition between (+)-Catechin and (-)-Epicatechin in AcetaldehydeInduced Polymerization of Flavanols. J. Agric. Food Chem. 47: 20882095.

Frangipane, M.T., Santis, D.D.E., and Ceccarelli, A. (2007). Influence of 
oak woods of different geographical origins on quality of wines aged in barriques and using oak chips. Food Chem. 103: 46-54. doi:10.1016/j.foodchem.2006.07.070.

Gallego, M.A.G., Sánchez-Palomo, E., Hermosín-Gutiérrez, I., and Viñas, M.A.G. (2015a). Effect of oak chip addition at different winemaking stages on phenolic composition of Moravia Agria red wines. S. Afr. J. Enol. Vitic. 36(1): 21-31.

Gallego, M.A.G., Sánchez-Palomo, E., Hermosín-Gutiérrez, I., and Viñas, M.A.G. (2015b). Effect of Oak Chip Addition at Different Winemaking Stages on Phenolic Composition of Moravia Agria Red Wines. S. Afr. J. Enol. Vitic. 36(1): 21-31.

García-Carpintero, E.G., Sánchez-Palomo, E., and González Viñas, M.A. (2014). Volatile composition of Bobal red wines subjected to alcoholic/malolactic fermentation with oak chips. LWT 55(2): 586-594. doi:10.1016/j.Iwt.2013.10.024.

Gordillo, B., Baca-bocanegra, B., Rodriguez-Pulído, F.J., González-Miret, M.L., García, I.E., Quijada-Morín, N., Heredia, F.J., and EscribanoBailón, M.T. (2016). Optimisation of an oak chips-grape mix maceration process. Influence of chip dose and maceration time. Food Chem. 206: 249-259. doi:10.1016/j.foodchem.2016.03.041.

Gordillo, B., Cejudo-Bastante, M.J., Rodríguez-Pulido, F.J., González-Miret, M.L., and Heredia, F.J. (2013). Application of the differential colorimetry and polyphenolic profile to the evaluation of the chromatic quality of Tempranillo red wines elaborated in warm climate. Influence of the presence of oak wood chips during fermentation. Food Chem. 141(3): 2184-2190. doi:10.1016/j.foodchem.2013.05.014.

Granato, D., Katayama, F.C.U., and Castro, I.A. (2012). Characterization of red wines from South America based on sensory properties and antioxidant activity. J. Sci. Food Agr. 92: 526-533. doi:10.1002/jsfa.4602.

Harbertson, J., and Spayd, S. (2006). Measuring phenolics in the winery. Am. J. Enol. Vitic. 57: 280-288.

Jackson, R.S. Vineyard Practice. Wine Science. Elsevier, pp. 143-306. doi:10.1016/B978-0-12-381468-5.00004-X.

Jordão, A.M., Lozano, V., Correia, A.C., and Gonzalez-SanJosé, M.L. (2017). Impact of different wood chip species (oak, acacia and cherry ) on evolution of individual anthocyanins, chromatic characteristics and antioxidant capacity in model wine solutions. Bio Web of Conferences 9: $1-5$. doi:10.1051/bioconf/20170902013.

Lee, J., Durst, R.W., and Wrolstad, R.E. (2005). Determination of total monomeric anthocyanin pigment content of fruit juices, beverages, natural colorants, and wines by the $\mathrm{pH}$ differential method: Collaborative study. J. AOAC Int. 88(5): 1269-1278. doi:10.5555/ jaoi.2005.88.5.1269.

Liu, S., Wang, S., Yuan, G., Ouyang, X., Liu, Y., Zhu, B., and Zhang, B. (2016). Effect of Oak Chips on Evolution of Phenolic Compounds and Color Attributes of Bog Bilberry Syrup Wine During Bottle-Aging. J. Food Sci. 81(11): 2697-2707. doi:10.1111/1750-3841.13532.

Natividade, M.M.P., Corrêa, L.C., Souza, S.V.C., Pereira, G.E., and Lima, L.C.O. (2013). Simultaneous analysis of 25 phenolic compounds in grape juice for HPLC: Method validation and characterization of São Francisco Valley samples. Microchemical J. 110: 665-674. doi:10.1016/j.microc.2013.08.010.

Ou, B.X., Chang, T., H, D., and P, R. (2013). Phenolic compounds, organic acids and antioxidant activity of grape juices produced from new Brazilian varieties planted in the Northeast Region of Brazil. J. AOAC Int. 96: 1372-1376.

Ribéreau-Gayon, P., Dubourdieu, D., Donéche, B., and Lonvaud, A. (2006). Handbook of enology: The microbiology of wine and vinifications. John Wiley and Sons Ltd., England.

Rodriguez-Solana, R., Rodriguez-Freigedo, S., Salgado, J.M., Domínguez, J.M., and Cortés-Diéguez, S. (2017). Optimisation of accelerated ageing of grape marc distillate on amicro-scale process using a Box-Benhken design: influence of oak origin, fragment size and toast level on the composition of the final product. Aust. J. Grape Wine R. 23: 5-14. doi:10.1111/ajgw.12249.

Rufino, M.S.M., Alves, R.E., Brito, E.S., Pérez-Jiménez, J., Saura-Calixto, F., and Mancini-Filho, J. (2010). Bioactive compounds and antioxidant capacities of 18 non-traditional tropical fruits from Brazil. Food Chem. 12: 996-1002.

Swain, T., and Hills, W.E. (1959). The phenolic constituents of Prunus domestica I.-The quantitative analysis of phenolic constituents. J. Agric. Sci. 10(1): 63-68. 